\title{
Interest Rate Interactions between Bangladesh and the US: Possible Pass Through From the US
}

\author{
Mohammed Saiful Islam ${ }^{1} \&$ Mohammad T. Uddin ${ }^{1}$ \\ ${ }^{1}$ Department of Economics, University of Chittagong, Chittagong 4331, Bangladesh \\ Correspondence: Mohammed Saiful Islam, Professor, Department of Economics, University of Chittagong, \\ Chittagong 4331, Bangladesh.
}

Received: May 9, 2020

doi:10.5539/ibr.v13n7p1
Accepted: May 25, 2020

Online Published: May 27, 2020

URL: https://doi.org/10.5539/ibr.v13n7p1

\begin{abstract}
This paper investigates the long run relationship between the interest rates of Bangladesh and the United Sates (US). Using time series quarterly data for the period 1972- 2019, the study finds that the nominal rate of the US positively influences the nominal rate of Bangladesh and they do maintain a long run relationship. Similar result is obtained by examining the real rates of both countries. However, in the latter case the study period covers from the third quarter of 1993 to the third quarter of 2019. Estimation of the error correction model signifies that in both cases policy rate of Bangladesh significantly responds to the error, which is the measure of deviation from long run equilibrium. Although interest rates of Bangladesh respond to the error in both cases, the speed of adjustment is much higher in case of the real rates. Empirical findings reveal that around 6\% error is corrected in every quarter if it is nominal rate whereas in the event of real rate the rate of error correction is almost $77 \%$. These findings indicate that small economy Bangladesh plans its policy rate taking account of the dynamics of the large economy the US, and such policy dependence is more apparent for real rate of interest.
\end{abstract}

Keywords: error correction, interest rate dependence, long-run relationship

JEL Classification: E43, E5, E58

\section{Introduction}

Interest rate policy is one of the fundamental concerns of the monetary authority of a country since the macroeconomic stability in terms of inflation and output largely depends on the dynamics of interest rate behavior. For many countries, especially for less developed countries like Bangladesh, nominal rates are controlled by the government and therefore a consistent policy is expected to be in place such that the parties directly or indirectly benefited or affected by the policy framework stay at the highest level of satisfaction or at the minimum level of dissatisfaction respectively. Although the nominal rate is under the direct control of policymakers, contemporaneous real rates have to be focused because negative real rates would indicate comparatively high inflation. Unlike the US, nominal rates in Bangladesh are fairly sticky but inflation rates mark significant fluctuation. The reason is that the developed country US follows a rule-guided interest rate policy whereas Bangladesh's policy rate is mostly discretionary (Islam \& Uddin, 2011). Since the US interest rate policy directly takes account of inflation rate, the real rates of interest in the US also vary along with nominal rates following fluctuations in inflation, but nominal and real rates of Bangladesh do not exhibit any such pattern. Figure 1 and 2 display the time paths of interest rates of two sample countries. 


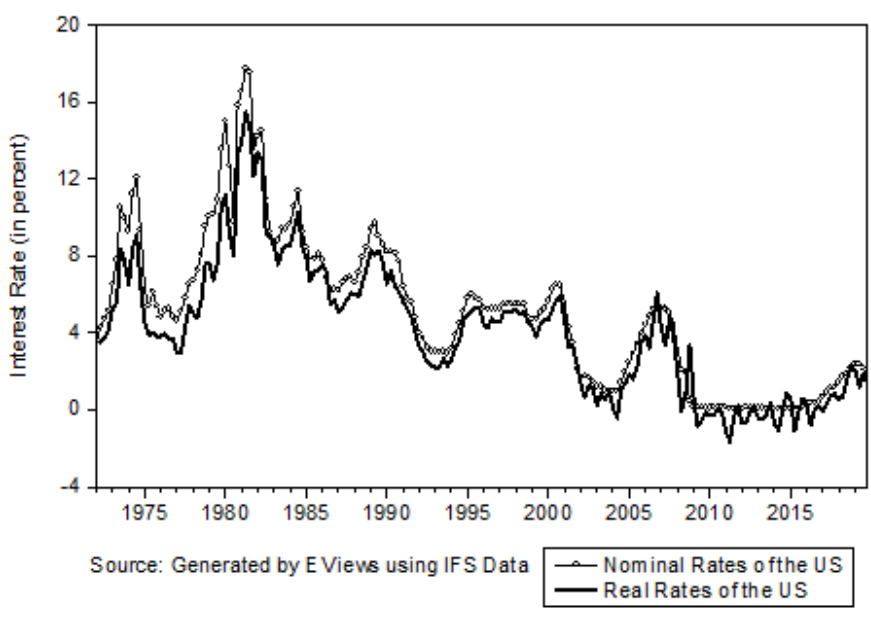

Figure 1. Nominal and Real Interest Rates of the US

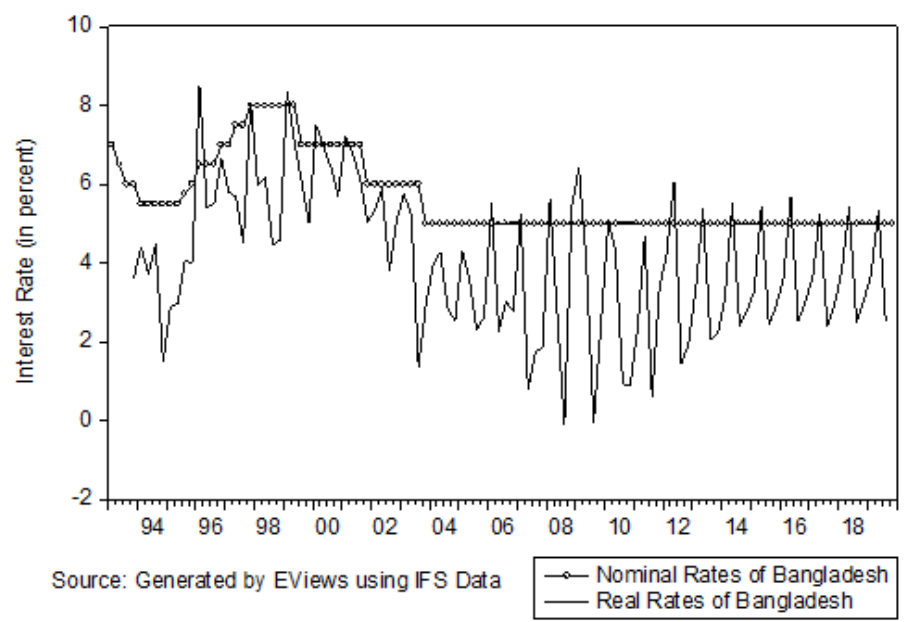

Figure 2. Nominal and Real Interest Rates of Bangladesh

Visual inspection of the policy rates of two countries does not provide the evidence of much resemblance. Apparently, real rates of both countries are fluctuating, and the reason of such variability is the contemporaneous movement in inflation. Figure 1 portrays that the nominal and real rates of the US do not deviate much because policy intentions of US actively accommodate inflation and thus the rates do not diverge away. Contrary to this, Bangladesh policy rates care very little about inflation and thereby generating a series of real rates that do not have close resemblance with the nominal rates. Having weaker financial market as well as fewer money market instruments, Bangladesh monetary policy authority resorts to a cautious policy formulation (Khan \& Ahmed, 2016). To avoid uncertainties, the country intends a fairly sticky and smoothened monetary policy interest rate. Despite a big difference in terms of underlying principles of policy rates, Bangladesh interest rate policy is seemingly guided by the US policy. Looking at the nominal interest rate series of two countries, the potential dependence of monetary policy interest rate of Bangladesh on the US becomes apparent.

Figure 3 may be useful to investigate the interest rate interactions between the countries. Both Bangladesh and the US raised policy rate in late 1980, and again during 1990-1995 the rates decreased. From 2010 onward both countries' interest rates remained moderately sticky. 


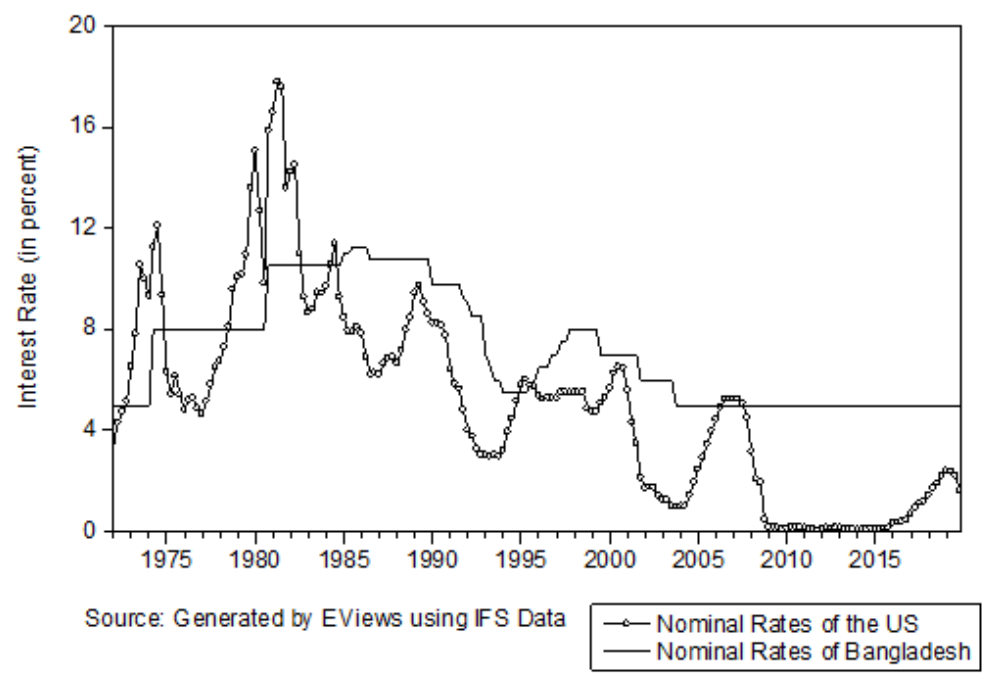

Figure 3. Nominal and Real Interest Rates of Bangladesh and the US

Plot of the nominal rates of the countries visually substantiates the linkage between two countries' monetary policy. Interest rates dependence is perceptible in the diagram. Obviously, the US should be in the lead because Bangladesh can take the US monetary policy as an input to their own policy making process given that the US has a good gauge of the economic conditions and a proficient monetary policy decision process (Cheung, Dickson \& Yiu, 2006). The close tie between the US and Bangladesh in terms of economic relation signifies the policy dependence. It is intuitively plausible to assume that the monetary authority of Bangladesh considers the US action while framing their own policy. Our objective is therefore to provide a reasonably robust empirical evidence of the policy rate dependence of Bangladesh on the US. The paper proceeds as follows. Next section highlights the possible sources of interdependence between the US and Bangladesh policy intentions. Section 3 is devoted to review the relevant literature. Section 4 presents the source of data and describes the methodology used in the study. Empirical results have been summarized in section 5 and finally section 6 illustrates policy implications and draws conclusion.

\section{Economic Interdependence of the US and Bangladesh}

Bangladesh maintains a close tie with the United States in relation to socio-economic and geo-political considerations. The US-Bangladesh politico-economic relationship dates back to 1972 through formal diplomatic recognition of Bangladesh as a sovereign nation-state. Just within two months of its recognition the US started giving economic assistance (in terms of food aid, commodity aid, and project aid) to Bangladesh with a view to overcoming two critical gaps - the domestic saving investment gap and the export-import gap — and has kept the inflow going over the years (Choudhury, 1992). However, due to Bangladesh's pro-USSR-India inclination during Sheikh Mujibur Rahman regime the US-Bangladesh economic relations were not so strong. The abrupt change of the Government in August 1975 marked a parametric shift in Bangladesh-US relations, especially during the period of Ziaur Rahman who adopted a pro-West policy. Over the last four decades, Bangladesh-US economic ties increasingly strengthened (Islam, 2019). About 30\% of total foreign aid and assistance is received by Bangladesh from the US. For example, the aid appropriation for Bangladesh from the USA for fiscal year 2000 was $\$ 66$ million including $\$ 77.4$ million in development assistance and $\$ 17$ million for food aid. ${ }^{1}$

Later in the 1990's, the US-Bangladesh relations gradually shifted from aid-assistance to trade and investment relations, which, in turn, have helped in growing trade and investment relationship between two countries. Since then the volume of foreign trade between Bangladesh and the US deliberately marks a steady increase. Economic attachment of Bangladesh with the US always benefits the former. Annual export earing of Bangladesh from the

${ }^{1}$ CRS Report for Congress, Congressional Research Service, The Library of Congress, Bangladesh: Background and US Relations, p.5. 
US is almost four times of import spending. United States is solely the largest destination of exports from Bangladesh. Nearly 300,000 Bangladeshis live in the US who contribute to the Bangladesh economy by sending remittance. The US is the most popular country of choice to be emigrated by Bangladeshi nationals. Dramatic increase in the number of Bangladeshi immigrants in the US from 5,000 in 1980 to 300,000 in 2019 signifies the degree of bonding between two countries.

Bangladesh also contributes to the prosperity of the US that has been acknowledged by the former US president Obama (Rivkin, 2014). Vaugh (2010) illustrates that among many others, trade, development, energy are the major components of American interests with Bangladesh. Real sector economy of Bangladesh is obviously benefited by the US action.

Volume of exports from the US to Bangladesh is always on the rise. The principal export industry of Bangladesh absorbing nearly 4 million workforces is the readymade garments (Rahman \& Anwar, 2006). US support extended through trade policy made it possible for Bangladesh to capture significantly large share of the market for apparels. As a single country, the US remains at the top in terms of the amount of foreign direct investment (FDI) in Bangladesh. For example, Bangladesh received 574 million US dollars from the US in 2015, which is one-fourth of the total global FDI into Bangladesh. Close connectivity of Bangladesh and the US is likely to result in win-win situation rather than win-lose (Aziz, 1982).

A good number of surveys have been carried out to delineate the interdependence of two countries - the US and Bangladesh. No study, however, was conducted exclusively to examine the monetary policy interdependence of these two countries. To the best of our knowledge, this is the first attempt to investigate any linkage between the interest rates of the US and Bangladesh. There are some studies, however, devoted to describe policy dependence of countries like China, Japan, Singapore, Malaysia, Korea, and Thailand on the US. The importance of interest rate interaction of a typical country with the US has substantial policy implications given that the country under consideration is linked with the US in terms of trade and nontrade activities. Next section documents the summaries of the researches specific to interest rate policies of several countries and interactions with the US.

\section{Literature Review}

Examining the behavior of interest rates of an economy turns out to be the focal concern of economists and practitioners when describing the conduct of monetary policy (Cúrdia, Ferrero, Ng, \& Tambalotti, 2015). Surpassing the research on an individual country alone, recently investigation on the policy interactions of various countries gained attention no matter how developed or underdeveloped they are. Monetary policy interdependence appears among different countries across the world, especially industrialized countries adhere such dependence more explicitly. Jorda and Bergin (2004) found significant policy interdependence among the OECD countries during the 1980-1998 period. The study observed a number of European countries to respond to German policy, and some other countries responding to the US policy. More interestingly, the policy harmonization works without any formal coordination.

Borensztein, Philippon, and Zettelmeyer (2001) investigated the interest rate dependence of Hong Kong, Singapore, Argentina and Mexico on the US interest rate and found that Hong Kong and Mexico significantly react to the interest rate policy of the US. These results have been derived using nominal rates alone, but Menzie and Frankel (1995) surveyed interactions among the real rates of several countries including USA, Japan, Singapore, Korea, Malaysia, Indonesia and Thailand. Their results indicate that the real rates of Hong Kong, Malaysia and Taiwan are influenced by both the US and Japan. Singapore's policy rate is linked with the US alone whereas Indonesia and Thailand appear to be more closely linked with Japan. Chow (2014) examined the interest rate transmission from the US to the Asian economies before and after the global financial crisis. The results support the evidence of possible pass through from the US to the Asian countries' policy interest rates.

Aleem and Lahiani (2011) found the State Bank of Pakistan reacting to the federal funds rate together with other variables in fixing their own monetary policy rate of interest. Forward-looking monetary policy rules have been estimated by the researchers for the State Bank of Pakistan where they found inflation and output gap to be significant. This finding supports the evidence of interest rate policy of Pakistan to be influenced by the federal rates.

Velickovic and Velickovic (2016) examined the interest rate policy of the developing countries and found it not to be market determined. According to the research, underdeveloped financial market, lack of sufficient financial instruments and interruption of the governments on central banks are responsible for such failure. Khan and Ahmed (2016) examined the way of monetary policy conduct of four Asian economies. The study reveals, Bangladesh does not accommodate inflation concern while setting monetary policy, rather the country substantially smoothens the interest rate for a quite longer period. Unlike Bangladesh, India, Pakistan and Sri 
Lanka focus inflation, foreign interest rate and real exchange rate movements in the setting of nominal rates. However, Ahmed and Islam (2004) find that Bangladesh is moving toward a market-based interest rate regime from almost a discretionary framework, thereby attracting investment and thus promoting economic growth. This finding is in accordance with the proviso that the country is attempting to harmonize its policy intentions with the countries following rule-based interest rates. This is a source of motivation in favor of the current research devoted to interpreting interest rate interaction between Bangladesh and the US.

Nyumuah (2018) advocates inflation targeting monetary policy for the developing countries, and the nominal rate of interest has been suggested as the policy instrument. Using quarterly data on four African countries, the author draws a firm conclusion proposing inflation targeting as a monetary policy rule. This conclusion has the similarity with the findings of Islam (2011) who conducted a study taking three developing countriesBangladesh, India and Pakistan and three developed countries- USA, UK and Sweden. The author measured social loss generated through inflation and output instability and found the amount of loss to stay at a minimum in case of the developed countries that follow rule-guided interest rate policy. As opposed to the developed countries, developing countries' monetary policies care little about any rule and thereby incurring huge social loss defined over inflation and output instability. Essentially, less developed countries with discretionary policy involve multidimensional uncertainties because the policymakers cannot anticipate the reactions of the public to the policy and they are unable to outguess one another thereby mismatching their expectations (Koppl, 2017). Developed economies feature the opposite.

According to Cúrdia, Ferrero, Ng, and Tambalotti (2015) interest rate decisions by central banks of most of the advanced countries including the US are universally rule-guided, which describe policy rates as responding to inflation and some measure of the output gap. Financial market of the US is far developed than Bangladesh. Having almost independent Federal Reserve System, the country launches its monetary policy targeting inflation and output stability. As opposed to this, Bangladesh's policy is constrained by the discretion of the government. However, we find evidence that intentionally or unintentionally Bangladesh's monetary policy interest rate is guided by the US policy, at least to a limited extent. This research is carried out to expose such policy dependence.

\section{Data and Methodology}

Quarterly data have been retrieved online from International Financial Statistics (IFS) of the IMF. Data on nominal rate of interest have been collected from the first quarter of 1972 (1972:Q1) to fourth quarter of 2019 (2019:Q4). Because of the unavailability of Bangladesh CPI for the entire span, we computed real interest rates from 1993:Q3 to 2019:Q3. Monetary policy rate or the bank rate has been accepted as the nominal rate of interest for Bangladesh. The data on monetary policy rate of the US is not available until the third quarter of 1982. But the money market interest rate is available for the whole period. Moreover, both these series exhibit a close resemblance which is visible in the following diagram. Therefore, we use money market interest rate of the US as the nominal interest rate.

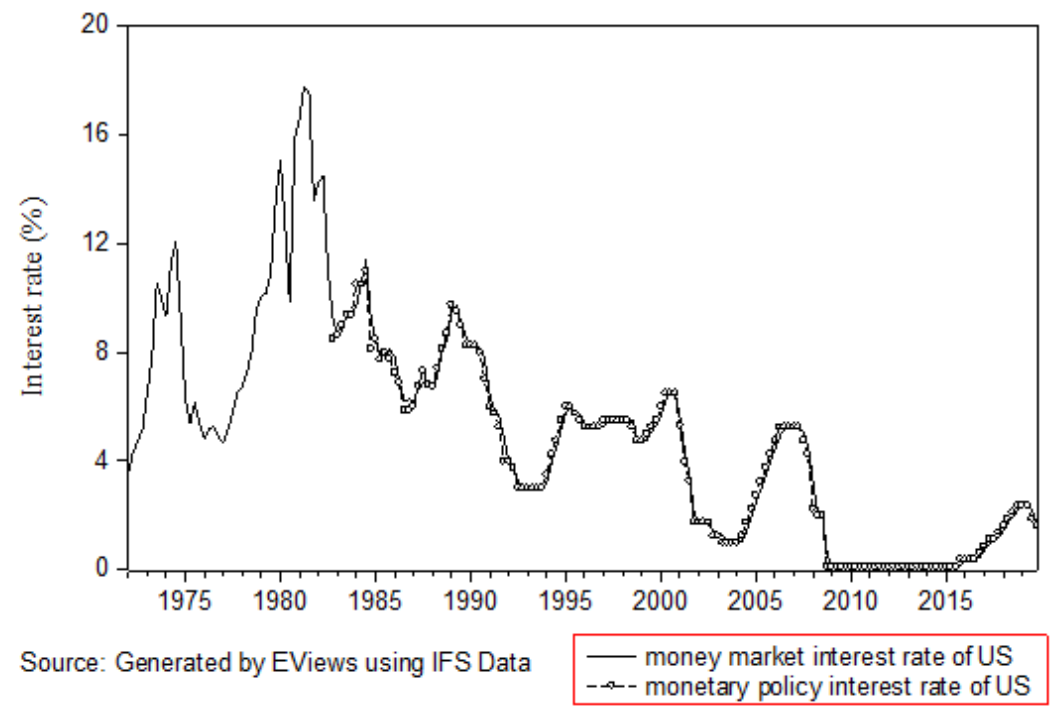

Figure 4. Monetary Policy Rate and Money Marker Interest Rate of the US 
Real rates of interests are not readily available, rather they have been calculated by deducting inflations from nominal rates of interest. Inflation is computed by taking the percentage of log differences of consumer price index (CPI).

Stationarity test has been performed by employing the augmented Dickey-Fuller (1979) test. Test equation includes an intercept and lags of dependent variable. Inclusion of intercept is justified by the nonzero mean of interest rates. Lagged dependent variable as the right-hand side variable solves the problem of autocorrelation. General specification of the test equation is:

$$
\Delta y_{t}=\alpha+\gamma y_{t-1}+\sum_{s=1}^{m} a_{s} \Delta y_{t-s}+v_{t}
$$

For nominal interest rate in Bangladesh $\left(i_{B}\right)$, the equation takes the form:

$$
\Delta i_{B, t}=\alpha_{1}+\gamma_{1} i_{B, t-1}+\sum_{s=1}^{m} a_{1 s} \Delta i_{B, t-s}+v_{t}^{i}
$$

Similarly, other test equations are

$$
\begin{gathered}
\Delta i_{U, t}=\alpha_{2}+\gamma_{2} i_{U, t-1}+\sum_{s=1}^{m} a_{2 s} \Delta i_{U, t-s}+v_{t}^{i} \\
\Delta r_{B, t}=\alpha_{3}+\gamma_{3} r_{B, t-1}+\sum_{s=1}^{m} a_{3 s} \Delta r_{B, t-s}+v_{t}^{r} \\
\Delta r_{U, t}=\alpha_{4}+\gamma_{4} r_{U, t-1}+\sum_{s=1}^{m} a_{4 s} \Delta r_{U, t-s}+v_{t}{ }_{t}^{U}
\end{gathered}
$$

Here, $r$ stands for real rate of interest and the subscript $U$ is attached to mean the country the US.

Null and alternative hypotheses of ADF test are respectively:

$$
H_{0}: \gamma_{i}=0, \text { and } H_{A}: \gamma_{i}<0
$$

If we are unable to reject the null hypothesis, it would mean that the series has unit root, indicating the non-stationarity of the respective series.

Since the United States is a large economy compared to the Bangladesh economy, it is reasonable to assume that the interest rate of Bangladesh is likely to be influenced by the interest rate of the US. There is a very little or no chance of US interest rates to be influenced by the interest rates in Bangladesh. However, we resort to the Granger causality test in order to examine the direction of pass through between these two series. Similar exercise has been performed by Muktadir (2012). Finally, long run cointegrating relationships between the interest rates of two countries are as below.

$$
\begin{aligned}
& i_{B}=\beta_{1}+\beta_{2} i_{U}+e_{i} \\
& r_{B}=b_{1}+b_{2} r_{U}+e_{r}
\end{aligned}
$$

Linear combinations of two series are: 


$$
\begin{array}{cc}
e_{i}=i_{B}-\beta_{1}-\beta_{2} i_{U} & \text { (8) (for nominal interest rate) } \\
e_{r}=r_{B}-b_{1}-b_{2} r_{U} & \text { (9) (for real interest rate) }
\end{array}
$$

If two series $\mathrm{y}_{\mathrm{t}}$ and $\mathrm{x}_{\mathrm{t}}$ are $\mathrm{I}(1)$ then their linear combination $e_{t}=y_{t}-\beta_{1}-\beta_{2} x_{t}$ is supposed to be $\mathrm{I}(1)$. In special case when $e_{t}$ is $\mathrm{I}(0)$ then it confirms that $y_{t}$ and $x_{t}$ are cointegrated. Therefore, cointegration test rests on the stationarity test of the residuals $\hat{e}_{t}$. In our study, we examine the order or integration of the series, and then of their linear combination.

A pair of variables maintaining cointegrating relation suggests that there is a long run relation between them. However, in short-run there may have some deviation or error that must be corrected over time for the existence of long run relation. An error correction model shows how the error is corrected in each period.

General form of the vector error correction model (VECM) is presented below.

$$
\begin{gathered}
\Delta y_{t}=\alpha_{10}+\alpha_{11}\left(y_{t-1}-\beta_{1}-\beta_{2} x_{t-1}\right)+v_{t}^{y} \\
\Delta x_{t}=\alpha_{20}+\alpha_{21}\left(y_{t-1}-\beta_{1}-\beta_{2} x_{t-1}\right)+v_{t}^{x}
\end{gathered}
$$

The coefficients $\alpha_{11}, \alpha_{21}$ are known as error correction coefficients, so named because they show how much $\Delta y_{t}$ and $\Delta x_{t}$ respond to the cointegrating error (Hill et al., 2011).

If $-1<\alpha_{11} \leq 0$ and $0 \leq \alpha_{21}<1$ then the stability of the model would be confirmed.

The VECM model has been estimated by applying two-stage least squares. In the first stage, the cointegrating relation $y_{t}=\beta_{1}+\beta_{2} x_{t}+e_{t}$ is estimated then the lagged residuals $\hat{e}_{t-1}=y_{t-1}-\hat{\beta}_{1}-\hat{\beta}_{2} x_{t-1}$ are generated. In second stage, following two error correction equations are estimated.

$$
\begin{aligned}
& \Delta y_{t}=\alpha_{10}+\alpha_{11} \hat{e}_{t-1}+v_{t}^{y}=\alpha_{10}+\alpha_{11}\left(y_{t-1}-\hat{\beta}_{1}-\hat{\beta}_{2} x_{t-1}\right)+v_{t}^{y} \\
& \Delta x_{t}=\alpha_{20}+\alpha_{21} \hat{e}_{t-1}+v_{t}^{x}=\alpha_{20}+\alpha_{21}\left(y_{t-1}-\hat{\beta}_{1}-\hat{\beta}_{2} x_{t-1}\right)+v_{t}^{x}
\end{aligned}
$$

The salient feature of this two-step procedure is that we avoid estimation by mixing stationary and nonstationary variables, thereby ruling out the possibility of spurious regression. For example, in the cointegrating equation $y_{t}=\beta_{1}+\beta_{2} x_{t}+e_{t}$, both $y_{t}$ and $x_{t}$ being I(1), the OLS estimation approach would be devoid of spurious result given that their linear combination $e_{t}$ is $\mathrm{I}(0)$. Again $y_{t}$ and $x_{t}$ being $\mathrm{I}(1)$, their first differences $\Delta y_{t}$ and $\Delta x_{t}$ would be $\mathrm{I}(0)$. Furthermore, $y_{t}$ and $x_{t}$ being cointegrated, their linear combination, with one period lag, $e_{t-1}=y_{t-1}-\beta_{1}-\beta_{2} x_{t-1}$ would also be $\mathrm{I}(0)$. This suggests, variables appearing in both sides of equation (10a) and (11a) are stationary, validating the least squares approach.

\section{Empirical Results}

Unit root test results for nominal and real interest rates of Bangladesh and the US are presented in Table 1. 
Table 1. Unit Root Test Results of Nominal and Real Interest Rates

\begin{tabular}{|c|c|c|c|c|c|c|}
\hline Series & Country & $\begin{array}{c}\text { Level or First } \\
\text { Difference }\end{array}$ & $\begin{array}{l}5 \% \text { ADF } \\
\text { test } \\
\text { statistic } \\
\text { critical } \\
\text { value }\end{array}$ & $\begin{array}{c}\text { Computed } \\
\text { value of ADF } \\
\text { test statistic }\end{array}$ & $\begin{array}{c}\text { Nature of the } \\
\text { series }\end{array}$ & $\begin{array}{c}\text { Order of } \\
\text { integration }\end{array}$ \\
\hline \multirow{4}{*}{$\begin{array}{c}\text { Nominal } \\
\text { Interest Rate }\end{array}$} & \multirow[b]{2}{*}{ Bangladesh } & Level & -2.88 & -1.12 & nonstationary & \multirow{4}{*}{$\mathrm{I}(1)$} \\
\hline & & $\begin{array}{c}\text { First } \\
\text { Difference }\end{array}$ & -2.88 & -12.92 & stationary & \\
\hline & \multirow[b]{2}{*}{ US } & Level & -2.88 & -1.95 & nonstationary & \\
\hline & & $\begin{array}{c}\text { First } \\
\text { Difference }\end{array}$ & -2.88 & -11.0 & stationary & \\
\hline \multirow{4}{*}{$\begin{array}{c}\text { Real Interest } \\
\text { Rate }\end{array}$} & \multirow[b]{2}{*}{ Bangladesh } & Level & -2.89 & -1.46 & nonstationary & \multirow{4}{*}{$\mathrm{I}(1)$} \\
\hline & & $\begin{array}{c}\text { First } \\
\text { Difference }\end{array}$ & -2.89 & -18.88 & stationary & \\
\hline & \multirow[b]{2}{*}{ US } & Level & -2.88 & -1.48 & nonstationary & \\
\hline & & $\begin{array}{c}\text { First } \\
\text { Difference }\end{array}$ & -2.88 & -12.94 & stationary & \\
\hline
\end{tabular}

Source: Authors' calculation using EViews 9

We observe, all four series are non-stationary and they are integrated of order one. The above results are based on the widely used augmented Dickey-Fuller (1979) test. Same conclusion can be drawn on the basis of Kwiatkowski-Phillips-Schmidt-Shin (1992) test. To save space, the test results of Kwiatkowski-Phillips-Schmidt-Shin (KPSS) test have not been presented here. Interest rates of both countries being integrated of equal order may underlie some sensible interactions between them. In order to investigate the possible pass through, we apply Granger causality test. Results of the tests pertaining to the nominal rates and real rates have been summarized in Table 2 and 3 respectively

Table 2. Pairwise Granger Causality Tests for Nominal Interest Rates

Sample: 1972Q1 2019Q4

Lags: 2

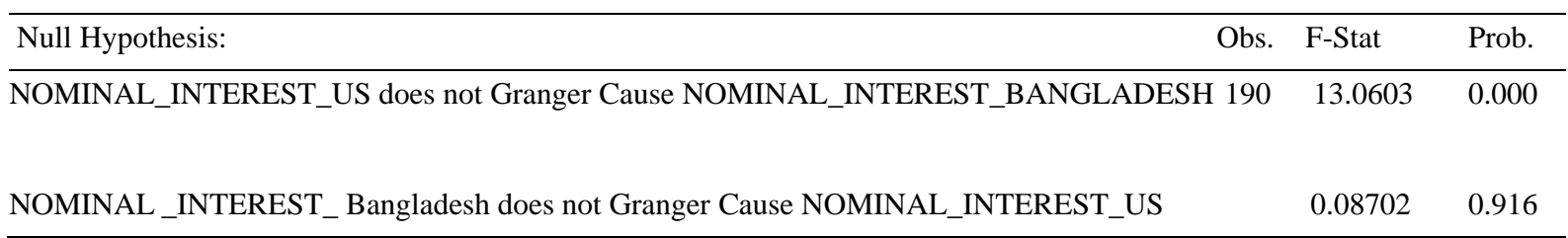

Source: Authors' calculation using EViews 9.

The null hypothesis of the US interest rate not Granger causing Bangladesh interest rate cannot be accepted but the hypothesis of Bangladesh interest rate not Granger causing US interest rate cannot be rejected. On the basis of the information documented in Table 2, we conclude that there is a unidirectional causality from the US interest rate to the Bangladesh interest rate.

Table 3. Pairwise Granger Causality Tests for Real Interest Rates

Sample: 1993Q3 2019Q4

Lags: 2

\begin{tabular}{lccc}
\hline Null Hypothesis: & Obs & F-Statistic & Prob. \\
\hline REAL_INTEREST_US does not Granger Cause REAL_INTEREST_Bangladesh & 102 & 10.2635 & 0.000 \\
REAL_INTEREST_Bangladesh does not Granger Cause REAL_INTEREST_US & & 9.70478 & 0.001 \\
\hline
\end{tabular}

Source: Author's calculation using EViews.

Table 3 shows bidirectional causality between the US and Bangladesh real rates. But we do not rely on this result because of two reasons. Firstly, the US authority is unlikely to formulate their interest rate policy looking at what 
Bangladesh is doing, and secondly the test is conducted by considering a smaller sample using data from 1993. Smaller sample size is due to the unavailability of CPI data of Bangladesh until the second quarter of 1993. Overall judgment manifests that the monetary authority of Bangladesh plans their interest rate policy taking account of the policy adopted by the United Sates.

Ordinary least squares (OLS) approach has been applied to investigate the cointegrating relationship between two countries' interest rates. Estimated equation for the nominal rate is as below.

$$
\underset{B}{\hat{i}_{B}}=\underset{(28.22)}{5.07}+\underset{(14.58)}{0.40} i_{U} \quad \mathrm{R}^{2}=0.53
$$

Series of residual:

$$
\hat{e}_{i}=i_{B}-5.07-0.40 i_{U}
$$

ADF test for checking the stationarity of residuals is performed. Test results suggest to reject the null hypothesis of non-stationarity because 5\% critical value of the ADF test statistic is -1.94 but the computed value is -2.68 . Stationarity of the residuals confirms the cointegrating relation between the nominal interest rates of Bangladesh and the US. Since the variables are cointegrated, OLS estimators are super-consistent (Hill, Griffiths, \& Lim, 2011). Corresponding error correction model has been estimated.

$$
\Delta i_{B, t}=\alpha_{10}+\alpha_{11}\left(i_{B, t-1}-5.07-0.40 i_{U, t-1}\right)+v_{1}
$$

Table 4. Estimation Output of Error Correction Equation for Bangladesh Nominal Rate

$$
\text { Dependent Variable: D(NOMINAL_INTEREST_BANGLADESH) }
$$

Method: Least Squares

Sample (adjusted): 1972Q2 2019Q4

Included observations: 191 after adjustments

\begin{tabular}{lcccc}
\hline Variable & Coefficient & Std. Error & t-Statistic & Prob. \\
\hline C & 0.000238 & 0.025148 & 0.009448 & 0.9925 \\
RESIDAUL_I(-1) & -0.061698 & 0.016594 & -3.718173 & 0.0003 \\
\hline
\end{tabular}

Source: Authors' calculation using EViews.

Error correction coefficient estimate: $\hat{\alpha}_{11}=-0.06$. This value satisfies the error correction coefficient restriction. From this, we infer that in each quarter $6 \%$ of the deviation from long-run equilibrium is made up. Although the speed of adjustment is slow, it is significant. This adjustment is done by the Bangladesh policy rate. However, to examine the US adjustment towards deviation we estimate the following equation.

$$
\Delta i_{U, t}=\alpha_{20}+\alpha_{21}\left(i_{B, t-1}-5.07-0.40 i_{U, t-1}\right)+v_{2}
$$


Table 5. Estimation Output of Error Correction Equation for US Nominal Rate

Dependent Variable: D(NOMINAL_INTEREST_US)

Method: Least Squares

Sample (adjusted): 1972Q2 2019Q4

Included observations: 191 after adjustments

\begin{tabular}{lllll}
\hline Variable & Coefficient & Std. Error & t-Statistic & Prob. \\
\hline C & -0.009727 & 0.067938 & -0.143176 & 0.8863 \\
RESIDAUL_I(-1) & -0.052748 & 0.044827 & -1.176694 & 0.2408 \\
\hline
\end{tabular}

Source: Authors' calculation using EViews.

Here we watch insignificant error correction coefficient. The insignificance of error correction coefficient lies in the fact that there is no reason why a large economy (the US) would change its interest rate in order for bringing back the equilibrium, which is the concern of the small economy Bangladesh.

The above findings are interesting as well as implicative, especially for Bangladesh. We now turn to investigate whether real rates of interests also maintain any such long-run relationship.

Quarterly data from 1993: Q4 to 2019: Q3 produce the following results.

Estimated equation:

$$
\underset{B}{\hat{r}_{B}}=\underset{(14.75)}{3.44}+\underset{(4.05)}{0.32} r_{U}
$$

Series of residual:

$$
\hat{e}_{r}=r_{B}-3.44-0.32 r_{U}
$$

Null hypothesis of residuals having unit root can be rejected because computed value of the ADF test statistic is -2.72 whereas the $5 \%$ critical value is -1.94 . Cointegrating relationship between real interest rates of two countries is evident from the stationarity of residuals. In the next step we estimate error correction models.

\begin{tabular}{|c|c|c|c|c|}
\hline \multicolumn{5}{|c|}{ Dependent Variable: D(REAL_INTEREST_BANGLADESH) } \\
\hline \multicolumn{5}{|c|}{ Method: Least Squares } \\
\hline \multicolumn{5}{|c|}{ Sample (adjusted): 1994Q1 2019Q3 } \\
\hline \multicolumn{5}{|c|}{ Included observations: 103 after adjustments } \\
\hline Variable & Coefficient & Std. Error & $\mathrm{t}$-Statistic & Prob. \\
\hline $\mathrm{C}$ & 0.000674 & 0.157518 & 0.004278 & 0.9966 \\
\hline RESIDUAL_R(-1) & -0.769795 & 0.091428 & -8.419670 & 0.0000 \\
\hline
\end{tabular}

$$
\Delta r_{B, t}=\gamma_{10}+\gamma_{11}\left(r_{B, t-1}-3.44-0.32 r_{U, t-1}\right)+e_{1}
$$

Table 6. Estimation Output of Error Correction Equation for Bangladesh Real Rate

Source: Authors' own calculation using EViews 9. 
Here, error correction coefficient estimate $\hat{\gamma}_{11}=-0.77$, which is negative but greater than -1 , thereby satisfying the error correction coefficient restriction. Speed of adjustment towards equilibrium is $77 \%$, which is substantially high. This suggests, the real rate of interest of Bangladesh corrects for $77 \%$ of the error in each quarter. To examine the response of US real interest, we estimate the second equation of vector error correction model. Estimation output is shown in Table 7.

$$
\Delta r_{U, t}=\gamma_{20}+\gamma_{21}\left(r_{B, t-1}-3.44-0.32 r_{U, t-1}\right)+e_{2}
$$

Table 7. Estimation Output of Error Correction Equation for US Real Rate

\begin{tabular}{lllll}
\hline $\begin{array}{l}\text { Dependent Variable: D(REAL_INTEREST_US) } \\
\text { Method: Least Squares }\end{array}$ & & \\
Sample: 1993Q3 2019Q4 & & & \\
Included observations: 105 & & & \\
\hline Variable & Coefficient & Std. Error & t-Statistic & Prob. \\
\hline C & -0.004300 & 0.082999 & -0.051804 & 0.9588 \\
RESIDUAL_R(-1) & -0.032975 & 0.048439 & -0.680757 & 0.4976 \\
\hline
\end{tabular}

Source: Authors' own calculation using EViews

In this circumstance, error correction term is insignificant providing the similar information that the large country is not responding to the error in short run for restoring the long-run relationship.

\section{Conclusion and Policy Implication}

With the aim of verifying any implicit interaction between the interest rates of the US and Bangladesh, this paper empirically examines the relation between interest rates of the two countries. Using quarterly data of both nominal and real interest rates, the study finds a significant pass through in the interest rates of Bangladesh from the US. Estimation output reveals that for one percent increase in the nominal rate of the US, Bangladesh's predicted increase in the nominal rate is 40 basis points. In case of real rates, the corresponding increase is 32 basis points. The empirical evidence of the US interest rate pass-through on Bangladesh interest rate is quite strong. Short run error correction models used in the research explore that Bangladesh policy rates actively respond to the deviation from long run equilibrium. The speed of adjustment towards long run equilibrium is however rapid in the case of real rates. No matter how speedily the gap is bridged, the surprising finding of this paper is the policy dependence of Bangladesh and the US. Such policy dependence has not been addressed so far. The reason why the issue remained unfocused is that the US with strong financial market intends market-based policy rate whereas the small country Bangladesh, with weak financial market and inadequate logistics, opts for fairly discretionary interest rate setting. Therefore, the possibility of any link between the policy rates of two countries has neither been noticed nor investigated.

We do not have much evidence, or it is beyond the scope of current study, that the Bangladesh policymakers intend money market policy rates taking explicit account of the US, but the discretionary policy rate of Bangladesh is seemingly driven by the US rate. From examination of data of both countries, we find robust empirical evidence of policy dependence. However, one note is in order here. Several studies concluded that the US and other developed nations frame their monetary policy interest rates targeting inflation and aggregate output, thereby involving minimum amount of social loss. Bangladesh, although not following any rule-based interest rate, can opt for such specification aiming at substantial increase in macroeconomic performance. Rather than remaining as a follower, an independent market-based interest rate policy might enhance the credibility of Bangladesh authority. Getting around the limitation of a relatively underdeveloped financial market prevailing in Bangladesh, a market determined policy intention would offer considerable economic gains including efficient allocation of resources. Undeniably, Bangladesh faces some complex problems including the burden of big volume nonperforming loans in the banking industry and the lack of corporate governance. Such obstacles might sometimes risk the success of our proposed policy. 


\section{References}

Ahmed, S., \& Islam, M. E. (2004). Interest rate responsiveness of investment spending in Bangladesh. The Bangladesh Development Studies, 30(1-2), 65-109. Retrieved from https://www.jstor.org/stable/40795688

Aleem, A., \& Lahiani, A. (2011). Monetary policy rules for a developing country: Evidence from Pakistan. Journal of Asian Economics, 22(6), 483-494. https://doi.org/10.1016/j.asieco.2011.07.001

Aziz, M. A. (1982). Bangladesh in United States Foreign Policy. Asian Affairs: An American Review, 9(4), 218-227. https://doi.org/10.1080/00927678.1982.10553756

Bergin, P. R., \& Jordà, Ò. (2004). Measuring monetary policy interdependence. Journal of International Money and Finance, 23(5), 761-783. https://doi.org/10.1016/j.jimonfin.2004.03.004

Borensztein, M. E., Philippon, M. T., \& Zettelmeyer, M. J. (2001). Monetary Independence in Emerging Markets: Does the Exchange Rate Regime Make a Difference? (No. 1). IMF Working Papers 01/1. https://doi.org/10.5089/9781451841633.001

Cheung, Y. W., Tam, D. C., \& Yiu, M. S. (2008). Does the Chinese interest rate follow the US interest rate?. International Journal of Finance \& Economics, 13(1), 53-67. https://doi.org/10.1002/ijfe.349

Chinn, M. D., \& Frankel, J. A. (1995). Who drives real interest rates around the Pacific Rim: the USA or Japan? Journal of International Money and Finance, 14(6), 801-821. https://doi.org/10.1016/0261-5606(95)00038-0

Choudhury, D. (1992). Bangladesh and the South Asian International System. Academic Publishers. 120.

Chow, H. K. (2014). International transmission of interest rates and the open economy trilemma in Asia. The Singapore Economic Review, 59(03), 1-18. https://doi.org/10.1142/S0217590814500209

Cúrdia, V., Ferrero, A., Ng, G. C., \& Tambalotti, A. (2015). Has US monetary policy tracked the efficient interest rate? Journal of Monetary Economics, 70(C), 72-83. https://doi.org/10.1016/j.jmoneco.2014.09.004

Dickey, D. A., \& Fuller, W. A. (1979). Distribution of the estimators for autoregressive time series with a unit root. Journal of the American statistical association, 74(366a), 427-431. https://doi.org/10.2307/2286348

Hill, R. C., Griffiths, W. E., \& Lim, G. C. (2011). Principles of econometrics. John Wiley \& Sons, Inc.

Islam, M. S. (2019). Bangladesh-US Relations in the Post 9/11 Era: Economic and Geo-strategic Dimensions (Unpublished Manuscript).

Islam, M. S. (2011). Suitability of Rule-based Monetary Policy for Developing Countries: Lessons from Developed Countries. Bank Parikrama, 35-36, 19-64

Islam, M. S., \& Uddin, M. T. (2011). Inflation targeting as the monetary policy framework: Bangladesh perspective. Economia. Seria Management, 14(1), 106-119.

Khan, M. A., \& Ahmed, A. M. (2016). Conducting monetary policy in South Asian economies: an investigation. The Pakistan Development Review, 55(3), 161-190. https://doi.org/10.30541/v55i3pp.161-190

Koppl, R. (2017). Rules vs. Discretion Under Computability Constraints. Review of Behavioral Economics, 4(1), 1-31. https://doi.org/10.1561/105.00000056

Kwiatkowski, D., Phillips, P. C., Schmidt, P., \& Shin, Y. (1992). Testing the null hypothesis of stationarity against the alternative of a unit root. Journal of econometrics, 54(1-3), 159-178. https://doi.org/10.1016/0304-4076(92)90104-Y

Muktadir-al-Mukit, D. (2012). Effects of interest rate and exchange rate on volatility of market index at Dhaka stock exchange. Journal of Business and Technology (Dhaka), 7(2), 1-18. https://doi.org/10.3329/jbt.v7i2.16451

Nyumuah, F. S. (2018). The impacts of interest rate and exchange rate volatilities on the demand for money in developing economies. International Journal of Economics and Finance, 10(3), 56-69. https://doi.org/10.5539/ijef.v10n3p56

Rahman, M., \& Anwar, A. (2006). Bangladesh apparels export to the US market: an examination of her competitiveness vis-à-vis China. Dhaka: Centre for Policy Dialogue (CPD) Working Paper 62.

Rivkin, C. H. (2014). U.S.-Bangladesh Trade and Investment Ties: A Partnership for Sustained Success. Press Release, Embassy of the United States of America to Bangladesh, 23 November.

Velickovic, D., \& Velickovic, J. (2016). Interest Rate and Growth in Developing Countries. Ekonomika, Journal 
for Economic Theory and Practice and Social Issues, 62(1350-2019-2191), 61-70. https://doi.org/10.22004/ag.econ.288844

Vaughn, B. (2010). Bangladesh: Political and Strategic Developments and US Interests. CRS Report for Congress, April 1. Retrieved April 27, 2020, from http://fas.org/sgp/crs/row/R41194.pdf

\section{Copyrights}

Copyright for this article is retained by the author(s), with first publication rights granted to the journal.

This is an open-access article distributed under the terms and conditions of the Creative Commons Attribution license (http://creativecommons.org/licenses/by/4.0/). 